Canadian University Music Review

Canadian University Music Review

Revue de musique des universités canadiennes

\title{
Jean Cocteau: Evangelist of the Avant-garde
}

\section{Tom Gordon}

Volume 22, numéro 1, 2001

Jean Cocteau: Evangelist of the Avant-garde

Jean Cocteau : évangéliste de l'avant-garde

URI : https://id.erudit.org/iderudit/1014495ar

DOI : https://doi.org/10.7202/1014495ar

Aller au sommaire du numéro

\section{Éditeur(s)}

Canadian University Music Society / Société de musique des universités canadiennes

ISSN

0710-0353 (imprimé)

2291-2436 (numérique)

Découvrir la revue

\section{Citer ce document}

Gordon, T. (2001). Jean Cocteau: Evangelist of the Avant-garde. Canadian

University Music Review / Revue de musique des universités canadiennes, 22(1),

1-2. https://doi.org/10.7202/1014495ar

All Rights Reserved (C Canadian University Music Society / Société de musique des universités canadiennes, 2002
Ce document est protégé par la loi sur le droit d'auteur. L’utilisation des services d'Érudit (y compris la reproduction) est assujettie à sa politique d'utilisation que vous pouvez consulter en ligne.

https://apropos.erudit.org/fr/usagers/politique-dutilisation/ 


\title{
INTRODUCTION-JEAN COCTEAU: EVANGELIST OF THE AVANT-GARDE
}

\author{
Tom Gordon, Guest Editor
}

It was the bibliophile and literary critic Adrienne Monnier who quipped of Jean Cocteau, "He is never the first to leap over the barricades, but he is always the one to plant the flag." Harsh perhaps, but not without substance as an assessment of Cocteau's position in the cultural history of the twentieth century. The cruel truth is that Cocteau does not rank among the first echelon of this century's most original artists. But Adrienne Monnier's assessment also hints at two critical aspects of Cocteau's career: he crossed borders-many of them-and he had a great talent for bringing the public's attention to these border crossings. Few artists of any age have worked in so many styles and across so many artistic media. Cocteau the poet; Cocteau the dramatist; Cocteau the artist/designer; Cocteau the critic; Cocteau the film maker; Cocteau the musical advocate; Cocteau the publicist. And he ranks among the very few artists of any age whose sheer visibility made them inevitable at the defining events of an epoch. A participant in so many of the great moments of twentieth-century art, he became both their emblem and their spokesman, raising the flag for movements from surrealism to neo-classicism; from the bejangled exoticism of the early Ballets russes to the austere symbolism of his enigmatic films.

In this special issue of the Canadian University Music Review we examine several new tangents of an already much chronicled career. The six essays will offer two complementary approaches to Cocteau on and across the borders of the arts of the twentieth century: interdisciplinary analysis and new criticism. A wide range of interdisciplinary approaches will be invoked in the analysis of selected works from among Cocteau's musical collaborations. Among these are the pre-Parade works prompted by Cocteau's musical discoveries in Le Sacre du printemps (Tom Gordon, Bishop's University and Memorial University of Newfoundland); Cocteau and the avant-garde collaborations at the Ballets suédois with members of Les Six (Jacinthe Harbec, Université de Sherbrooke); and the fruits of the long working relationship Cocteau enjoyed with composer Georges Auric across the seven films they made together (Simon Wood, York University, and James Deaville, McMaster University). The insightful results of a wide range of analytical techniques drawn from the new criticism will bring Cocteau's achievement into new perspective. These essays will include a postmodernist look at Parade (Daniel Albright, Eastman School of Music); an exploration of technology as the focalizer of music theatre in the Cocteau-Poulenc monodrama, La Voix humaine (Lynette Miller Gottlieb, 
Kenyon College); and an essay informed by queer theory that explores the concepts of influence, emasculation and autobiography in the same CocteauPoulenc collaboration (Keith Clifton, Central Michigan University).

The conclusions that these essays bring us to are numerous and varied. Cocteau was, for most of his creative life, in the centre ring of the circus of experimental artistic activity in France. Music was virtually the only art medium in which Cocteau could not claim the role of practitioner. But as an evangelist, Cocteau voiced preoccupations of the musical avant-garde across the first half of the twentieth century. His close association with some of the seminal moments of twentieth-century music and his affiliation key figures and movements informed his provocative voice with authority. These analyses, from their broad range of perspectives, permit a deeper view of the coherence between Cocteau's activity as a creator and his role in and understanding of the musical avant-garde in France during the first half of the twentieth century. 